\section{Fall- and Spring-sown Cover Crop Mulches Affect Yield, Fruit Cleanliness, and Fusarium Fruit Rot Development in Pumpkin}

\author{
Christian A. Wyenandt ${ }^{1,4,7,8}$, Richard M. Riedel ${ }^{1,5}$, \\ Landon H. Rhodes ${ }^{1,6}$, Mark A. Bennett ${ }^{2}$, \\ and Stephen G.P. Nameth ${ }^{3}$
}

AdDITIONAL INDEX WORDs. Fusarium solani f. sp. cucurbitae, annual medic, Medicago truncatula, M. polymorpha, winter rye, Secale ceveale, hairy vetch, Vicia villosa

SUMMARY. In 2001 and 2002, fall- and spring-sown, spring-killed or spring-sown living cover crops mulches were evaluated for their effects on pumpkin (Cucurbita pepo) number and weight, fruit cleanliness, and fusarium fruit rot (FFR;

Fusarium solani f. sp. cucurbitae race 1). In general, the number and weight of orange (mature) fruit and total fruit weight were higher in bare soil (conventional), fall- or spring-sown, spring-killed cover crop mulches compared with spring-sown, living annual medic (Medicago spp.) cover crop mulches. In both years, pumpkins grown on fall-sown winter rye (Secale cereale), hairy vetch (Vicia villosa), winter rye + hairy vetch, and spring-sown oat (Avena sativa) produced fruit numbers and weights comparable to or slightly higher than bare soil (conventional) production, suggesting that these cover crop mulches had no effects on reducing pumpkin yield. The number and weight of pumpkins grown in spring-sown, living annual medic cover crop mulches were reduced in both years compared with the other cover crop mulches. On artificially inoculated field plots, percentages of groundcover at harvest and fruit with FFR were $89 \%$ and $5 \%$ in fall-sown winter rye (seeded at $90 \mathrm{lb} /$ acre), $88 \%$ and $10 \%$ in fall-sown rye $(50 \mathrm{lb} /$ acre $), 85 \%$ and $5 \%$ in fallsown rye + hairy vetch $(50 \mathrm{lb} /$ acre each), $19 \%$ and $30 \%$ in fall-sown hairy vetch $(50$ $\mathrm{lb} /$ acre), $23 \%$ and $23 \%$ in spring-sown oat (110 lb/acre), $1 \%$ and $25 \%$ to $39 \%$ in spring-sown, living annual medics (40 lb/acre) and $0 \%$ and $46 \%$ in bare soil plots, respectively. Results suggest that cover crop mulches such as fall-sown winter rye, fallsown winter rye + hairy vetch, or spring-sown, spring-killed oat killed and left on the soil surface may help reduce losses to FFR in pumpkin production.

$\mathrm{F}$ usarium fruit rot is an important soil-borne fungal disease of cucurbit crops (Zitter et al., 1996). Fusarium solani f. sp. cucurbitae race 1 was the most common species causing fruit rot of pumpkin in a survey of commercial fields in Ohio from 2000 to 2002 (Fig. 1) (Wyenandt et al., 2010) and was also confirmed

\footnotetext{
${ }^{1}$ Department of Plant Pathology, The Ohio State University, Columbus, OH 43210

${ }^{2}$ Professor, Department of Horticulture and Crop Science, The Ohio State University, Columbus, $\mathrm{OH}$ 43210

${ }^{3}$ Director and Professor, The Ohio State University Agricultural Technical Institute, Wooster, OH 44691

${ }^{4}$ Former Graduate Research Assistant

${ }^{5}$ Retired Professor

${ }^{6}$ Retired Associate Professor

${ }^{7}$ Current address: Extension Specialist in Vegetable Pathology, Department of Plant Biology and Pathology, Rutgers University, New Jersey Agricultural Experiment Station, Rutgers Agricultural Research and Extension Center, 121 Northville Road, Bridgeton, NJ 08302 .

${ }^{8}$ Corresponding author. E-mail: wyenandt@rutgers.edu.
} and fruit rot outbreaks in pumpkin in Connecticut, New York, and Missouri during 2001-03 (Elmer et al., 2007). Fusarium fruit rot can be extremely destructive in small roadside farm markets where "u-pick" pumpkins are planted in the same field each year. In some years in Ohio, yield loss was as high as $100 \%$ where pumpkin rotations are nonexistent, or every 1 or 2 years (Wyenandt et al., 2010). Using as the causal agent of fusarium foot cover crop mulches in pumpkin production may play an important role in reducing soil-borne fungal diseases when proper crop rotations cannot be done. Cover crops have been used in low- or high-input agronomic and vegetable production systems to help reduce soil erosion, fungicide use, plant disease, and weed pressure (Ellis et al., 1998; Hoyt, 1999; Jones et al., 1969; Louws et al., 1996; Masiunas et al., 1995; Mills et al., 2002; Putnam, 1990; Ristaino and Johnston, 1999; Sumner et al., 1986). Cover crops have also been shown to increase soil organic matter (SOM), nitrogen availability, and soil moisture (Blevins et al., 1971; Gallaher, 1977; Hoyt and Hargrove, 1986; Teasdale and Daughtry, 1993). Cover crop mulches have been shown to have negative, no impact, or positive effects on vegetable yields (AbdulBaki and Teasdale, 1993; Abdul-Baki et al., 1996a, 1996b; Creamer et al., 1996; Doss et al., 1981; Koike et al., 1997; Knavel and Herron, 1986; Louws et al., 1996; McKeown et al., 1998; NeSmith et al., 1994; Wyenandt et al., 2008a, 2008b). Cover crops may also increase disease in subsequent crops (Koike et al., 1997).

Traditional cover crops used in the midwestern United States, such as hairy vetch and winter rye that are killed and left on the soil surface, have been evaluated in pumpkin production (Everts, 2002; Galloway and Weston, 1996). Cover crops can be killed with herbicide applications or mechanically by roll chopping, crimping, flail mowing, or undercutting before no-till planting (Creamer et al., 1995, 1996). Vegetable production systems involving cover crop mulches, such as zone- or striptillage, are systems where planting strips are killed with herbicide or rotovated before vegetable seeding or transplanting. In other systems, such as hybrid mulch systems, cover crop mulches are

\begin{tabular}{lllc}
\hline $\begin{array}{l}\text { Units } \\
\begin{array}{l}\text { To convert U.S. to SI, } \\
\text { multiply by }\end{array}\end{array}$ & U.S. unit & SI unit & $\begin{array}{l}\text { To convert SI to U.S., } \\
\text { multiply by }\end{array}$ \\
\hline 29.5735 & $\mathrm{fl} \mathrm{oz}$ & $\mathrm{mL}$ & 0.0338 \\
0.0970 & $\mathrm{fl} \mathrm{oz} / 1000 \mathrm{ft}$ & $\mathrm{mL} \cdot \mathrm{m}^{-1}$ & 10.3065 \\
73.0778 & $\mathrm{fl} \mathrm{oz} / \mathrm{acre}$ & $\mathrm{mL} \cdot \mathrm{ha}^{-1}$ & 0.0137 \\
0.3048 & $\mathrm{ft}$ & $\mathrm{m}$ & 3.2808 \\
0.0929 & $\mathrm{ft}^{2}$ & $\mathrm{~m}$ & 10.7639 \\
2.54 & inch $(\mathrm{es})$ & $\mathrm{cm}$ & 0.3937 \\
1.1209 & $\mathrm{lb} / \mathrm{acre}$ & $\mathrm{kg} \cdot \mathrm{ha}^{-1}$ & 0.8922 \\
70.0532 & $\mathrm{oz} / \mathrm{acre}$ & $\mathrm{g} \cdot \mathrm{ha}^{-1}$ & 0.0143 \\
1.1692 & $\mathrm{pt} / \mathrm{acre}$ & $\mathrm{L} \cdot \mathrm{ha}^{-1}$ & 0.8553 \\
2.2417 & ton/acre & $\mathrm{Mg} \cdot \mathrm{ha}^{-1}$ & 0.4461 \\
$\left({ }^{\circ} \mathrm{F}-32\right) \div 1.8$ & ${ }^{\circ} \mathrm{F}$ & ${ }^{\circ} \mathrm{C}$ & $\left(1.8 \times{ }^{\circ} \mathrm{C}\right)+32$
\end{tabular}

Hortlechnology $•$ June $201121(3)$ 
seeded in the furrows between rows of plastic mulch in the early spring and then killed with herbicide before seeding or transplanting, or allowed to remain as living mulches during the production season (C.A. Wyenandt, R.M. Riedel, M.A. Bennett, and L.H. Rhodes, unpublished data).

Production problems may arise in small roadside farm operations trying to incorporate fall-sown cover crops such as winter rye, hairy vetch, or both in pumpkin production systems. These include having a field available in the fall for cover crop seeding, the proper timing of fall seeding, potential winter kill, timing of spring desiccation, and the potential for herbicide drift when killing the cover crop. In some cases, simply having too much aboveground cover crop biomass in the spring can make it difficult to strip- or no-till plant into the cover crop mulch if the proper no-till equipment is not used. Incorporating the use of spring-sown, living or spring-sown, spring-desiccated cover crop mulches, such as oat, may help alleviate some of the problems associated with incorporating the use of fall-sown cover crops in some small vegetable farm operations. Living cover crop mulches have been evaluated as cover crops in agricultural and vegetable production (Masiunas, 1998; Paine and Harrison, 1993). Spring-sown living cover crop mulches, such as annual medic, have been evaluated in the midwestern United States as emergency forage crops and as contributors of nitrogen to the soil (Shrestha et al., 1998; Zhu et al., 1996).

Very few field studies have been done to examine the role of cover crop mulches on the development of soil-borne fungal pathogens in pumpkin production. Everts (2002) determined that pumpkin grown on a fall-sown hairy vetch or a hairy vetch plus winter rye cover crop had an average of $36 \%$ less plectosporium blight (Plectosporium tabacinum) and $50 \%$ less black rot (Didymella bryoniae) than those grown with conventional tillage on bare ground. Although the mechanism by which disease was reduced was not studied, the hairy vetch + winter rye cover crop mulch resulted in a thick and long-lasting barrier between fruit and the ground and provided greater reduction in disease than hairy vetch alone (Everts, 2002). Rutledge (1999) in a review of conservation tillage vegetables in Tennessee suggested that crops that can be produced satisfactorily on cover crops can be harvested in cleaner condition, which can reduce cleaning costs to the packer, grower, or processor. Rutledge (1999) also suggested that with a residue cover, growers can get into fields sooner after a rain or irrigation event with reduced equipment slippage and with reduced soil erosion due to mechanical rutting of the land. Failure to obtain a good stand of the cover crop results in a very thin groundcover, increased weed problems, and unclean fruit due to adherence of soil particles (Rutledge, 1999).

The objectives of this study were to determine the effects of fall- and

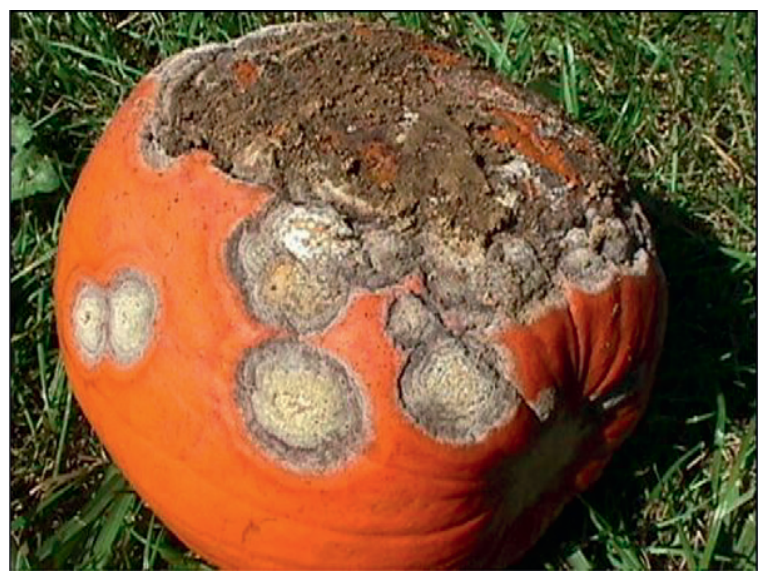

Fig. 1. Fruit rot caused by Fusarium solani f. sp. cucurbitae race 1 on mature pumpkin.

Table 1. Seeding rates for fall- and spring-sown cover crops evaluated at Ohio Agricultural Research Development Center's research farms in Ohio from 2000 to 2002 .

\begin{tabular}{lcc}
\hline & \multicolumn{2}{c}{ Seeding rate (lb/acre) } \\
\cline { 2 - 3 } Cover crop $^{\mathrm{z}}$ & $\mathbf{2 0 0 1}$ & $\mathbf{2 0 0 2}$ \\
\hline BS-fungicide & 0 & 0 \\
BS-no fungicide & 0 & 0 \\
FS winter rye & 90 & 90 \\
FS winter rye + hairy vetch & \\
FS winter rye & 50 & 50 Each \\
FS hairy vetch' & - & 50 \\
SL 'Sephi' medic & 40 & 50 \\
SL 'Polygraze' medic & 40 & 40 \\
SS 'Armor' oat & 110 & 40 \\
\hline
\end{tabular}

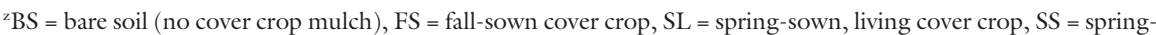
sown cover crop mulch. Pumpkins grown in BS-no fungicide treatments did not receive any fungicide maintenance applications for powdery mildew control the entire growing season. All other cover crop treatment plots received regularly scheduled fungicide applications for cucurbit powdery mildew control.

${ }^{\mathrm{y}} \mathrm{l} \mathrm{lb} / \mathrm{acre}=1.1209 \mathrm{~kg} \cdot \mathrm{ha}^{-1}$

x Fall-sown hairy vetch cover crop mulch seeded in Oct. 2000 for the 2001 production season froze out after establishment and, therefore, were not included in data analysis; (-), not applicable. 
Branch, Ohio Agricultural Research and Development Center (OARDC), Fremont, $\mathrm{OH}$, on a Hoytville silt loam soil with a $\mathrm{pH}$ of 6.5 and less than 2\% SOM; at the Western Branch (OARDC), South Charleston, OH, on a Crosby silt loam soil with a $\mathrm{pH}$ of 6.5 and less than $2 \%$ SOM; and at the Snyder Farm (OARDC), Wooster, $\mathrm{OH}$, on a Canfield silt loam soil with a pH of 6.5 and less than $2 \%$ SOM. In both years, all plots were $25 \times 25 \mathrm{ft}^{2}$. Seeding rates for cover crop mulch treatments for both years are presented in Table 1. A timeline of activities for cover crop establishment, cover crop kill, pumpkin seeding and harvest, and other production practices for both years are presented in Table 2.

Artificial inoculation of PUMPKIN FIELD IN WOOSTER, OH, WITH FFR. In Fall 2001, healthy mature pumpkin fruit 'Magic Lantern' were collected from a field at the Snyder Farm in Wooster, OH. All fruit were cleaned by rinsing with water, wiped down with $95 \%$ ethyl alcohol, and stored in a dry environment for future use. Each fruit was stab inoculated with a 4-week-old isolate of F. solani f. sp. cucurbitae race $\mathrm{l}$ by puncturing the fruit five times with a sterilized needle, then inoculated by placing a piece of culture on the wounded area. A piece of clear tape was placed over each inoculation site, and the pumpkin fruit were placed back into dry storage and allowed to rot for 8 weeks. In Jan. 2002 after symptoms had begun to develop, all inoculated fruit were placed into a manure spreader (V-tank Scavenger; Gehl, West Bend, WI). The manure spreader was used to grind the fruit into a thick, liquid pulp, then to uniformly distribute the pulp to inoculate the entire field before the 2002 production season.

ESTABLISHMENT OF SPRING-SOWN COVER CROP MULCHES. In Apr. and May 2001 and 2002, spring-sown cover crop treatments of 'Armor' oat, annual 'Sephi' or 'Parabinga' barrel medic (Medicago truncatula), or 'Polygraze' burr medic (Medicago polymorpha) were established in the same field plot as the fall-sown cover crops established the previous fall. Seeding rates and dates of establishment for spring-sown cover crop mulches are presented in Tables 1 and 2 .

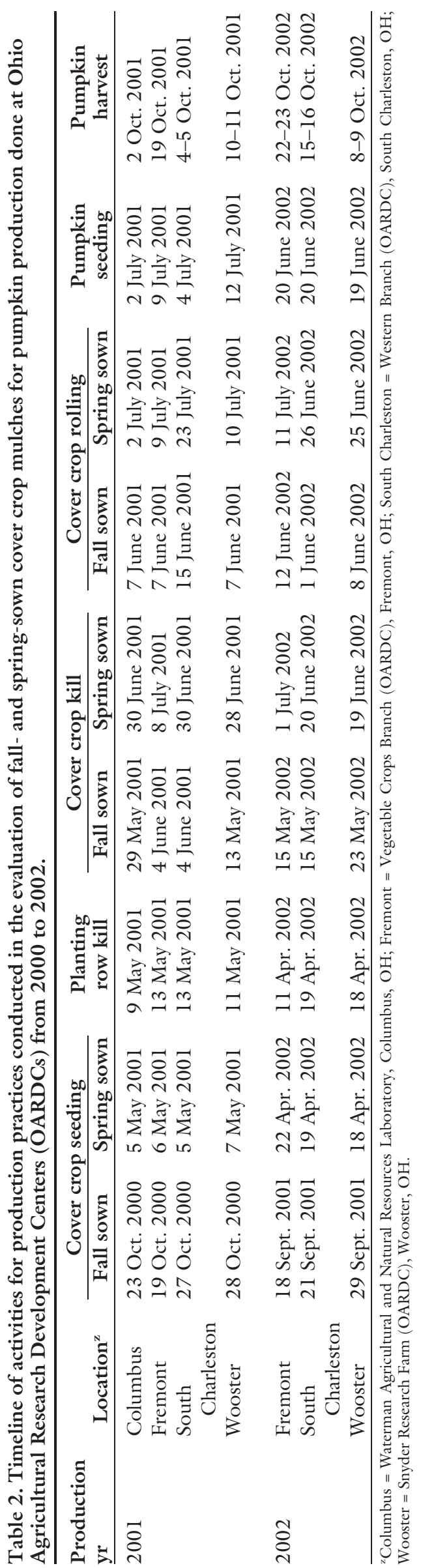


Preparation of Cover Crop MULCH TREATMENTS BEFORE PUMPKIN SEEDING. In Spring 2001 and 2002, two 2 -ft-wide wide planting strips on 10 -ft centers for strip-tillage production were made by applying 1.64 pt/acre glyphosate to all cover crops (Roundup Ultra; Monsanto, St. Louis, MO) with a backpack sprayer. In May or June of 2001 and 2002, all fall-sown winter rye plots were killed with $1.64 \mathrm{pt} /$ acre glyphosate. In treatments with hairy vetch, $1.25 \mathrm{pt} /$ acre 2,4-D (Weedone LV4; Rhone-Poulec, Research Triangle Park, NC) was applied with glyphosate. In June or July 2001 and 2002, all spring-sown oat treatments were killed with 1.64 pt/ acre glyphosate (Table 2 ).

In June 2001 and 2002, all falland spring-sown cover crop mulch treatments were rolled flat with an 18 -inch by 24 -inch-wide walk-behind polyethylene lawn roller and allowed to lie on the soil surface during the production season. In both years, annual medics were allowed to remain as living cover crop mulches during the production season (Table 2 ).

In June 2001 or $2002,0.38$ pt/ acre sethoxydim (Poast Plus; BASF, Research Triangle Park, NC) + 2,4-D was sprayed on annual medic plots to control grass and broadleaf weeds. At Fremont in 2002, no weed control was done in spring-sown annual medic treatments due to inclement weather when herbicide application needed to be done (Table 2).

\section{Pumpkin seeding and harvesting}

Planting STRIP ESTABlishment, SEEDING, FUNGICIDE MAINTENANCE, AND FERTILITY PROGRAMS. Before pumpkin seeding, planting strips were tilled with a 24 -inch-wide rear tine rototiller (Troy-Bilt, Cleveland, $\mathrm{OH})$. In both years, pumpkin 'Magic Lantern' (Harris Seeds, Rochester, NY) were direct seeded (two seed/ hill) by hand every $2 \mathrm{ft}$ using $\approx 8.0 \mathrm{fl}$ $\mathrm{oz}$ water plus $0.55 \mathrm{fl} \mathrm{oz} / 1000 \mathrm{ft}$ of row imidacloprid (Admire 2F; Bayer CropScience, Research Triangle Park, NC) (Table 2). Fungicide sprays for cucurbit powdery mildew (Podosphaera xanthii) control were done about every $14 \mathrm{~d}$ by applying $2.2 \mathrm{lb} /$ acre chlorothalonil (Bravo Ultrex 82.5WDG; Syngenta Crop Protection, Greensboro, $\mathrm{NC}$ ) $+2.0 \mathrm{oz} /$ acre myclobutanil (Nova 40WP; Dow AgroSciences, Indianapolis, IN) or $1.0 \mathrm{lb} /$ acre benomyl (Benlate
50WP; DuPont Agricultural Products, Wilmington, DE) rotated with $1.41 \mathrm{fl}$ oz/acre azoxystrobin (Quadris 2F; Syngenta Crop Protection) in both years, with the exception of a nonfungicidesprayed bare soil (conventional) plot in each year. In 2001 and 2002 , sulfur-coated urea $(39 \mathrm{~N}-0 \mathrm{P}-0 \mathrm{~K}$; Lesco, Rocky River, $\mathrm{OH}$ ) was broadcast at a rate of $50 \mathrm{lb} /$ acre nitrogen over each plot at pumpkin seeding and banded at the same rate by hand in planting strips at vine tip. About 1 inch of water was applied weekly using drip or overhead irrigation at Columbus, Fremont, and Wooster in 2001, at Fremont and Wooster in 2002, and on an as-needed basis depending on weather conditions.

Percent groundcover and COVER CROP BIOMASS DETERMINATION. In each year at pumpkin seeding and harvest, percent groundcover and aboveground biomass for each cover
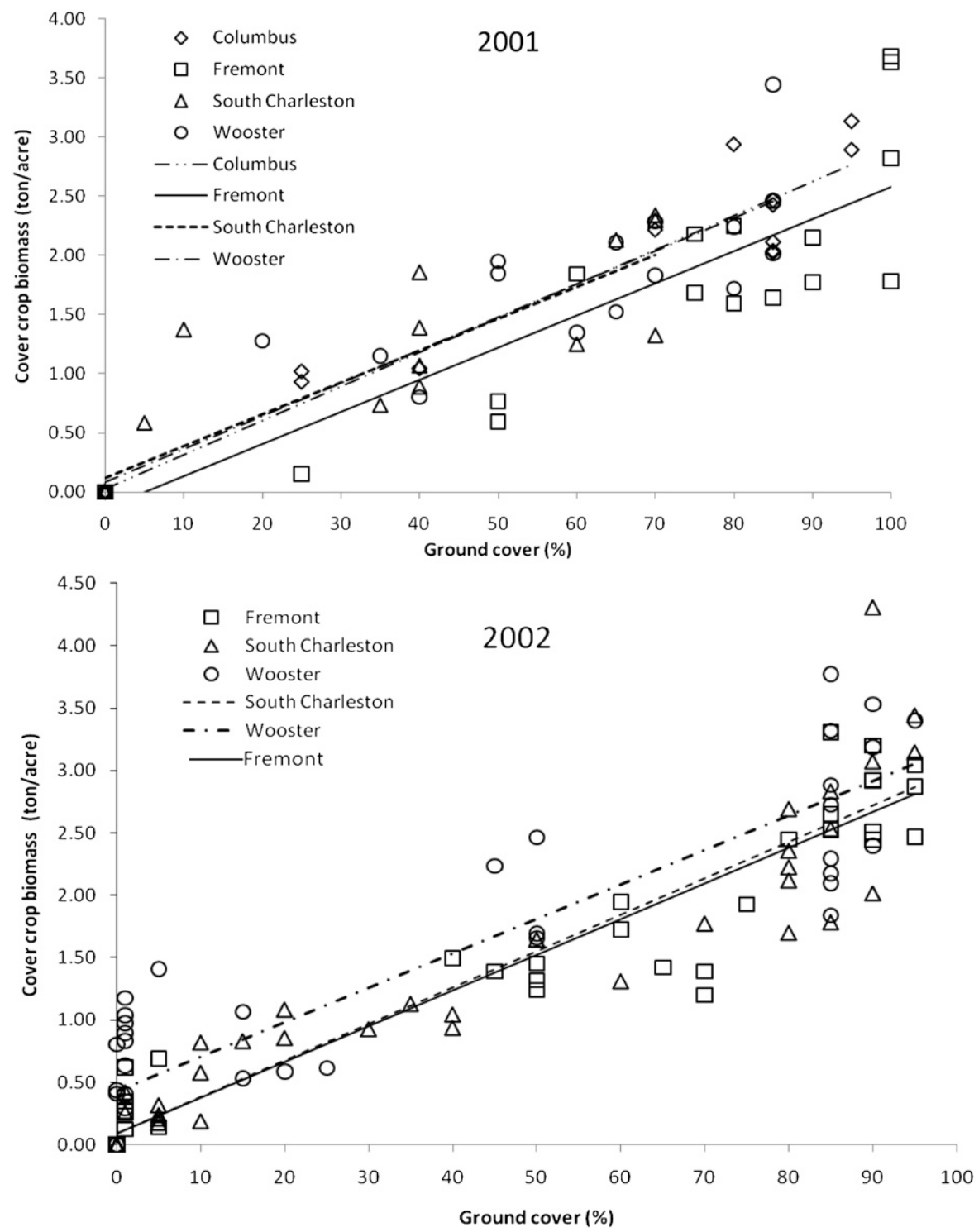

Fig. 2. Relationship between dry weight of cover crop mulches and the percentage of soil surface covered by cover crop mulch at pumpkin harvest at four Ohio Agricultural Research Development Centers in Ohio in 2001 and 2002.

Correlation equations in 2001 were $y=0.0288 x+0.0281(r=0.98)$ for Columbus; $y=0.0272 \mathrm{x}+0.1429(r=0.91)$ for Fremont; $y=0.269 \mathrm{x}+0.1226(r=0.90)$ for South Charleston; and $y=0.0280 \mathrm{x}+0.0803(r=0.93)$ for Wooster, $\mathrm{OH}$.

Correlation equations in 2002 were $y=0.0287 x+0.0879(r=0.96)$ for Fremont; $y=0.0292 \mathrm{x}+0.0933(r=0.94)$ for South Charleston; and $y=0.277 \mathrm{x}+\mathbf{0 . 4 2 4 7}$ $(r=0.91)$ for Wooster, $\mathrm{OH} ; 1$ ton $/$ acre $=2.2417 \mathrm{Mg} \cdot \mathrm{ha}^{-1}$. 
crop mulch treatment was estimated. All aboveground biomass from an area $\left(1 / 8 \mathrm{~m}^{2}\right)$ in the center of each cover crop was collected from three replications at pumpkin seeding and four replications harvest at each site in both years. Aboveground biomass was dried at $75{ }^{\circ} \mathrm{C}$ for $72 \mathrm{~h}$ and weighed to extrapolate dry weight (tons/acre). Average percent groundcover (i.e., the percentage of the soil surface covered by the cover crop mulch) at pumpkin seeding and harvest was determined by visually estimating an area $\left(1 / 2 \mathrm{~m}^{2}\right)$ in the center of each plot using a scale of $0.0-1.0$ using 0.05 increments.

PUMPKIN HARVEST, FRUIT CLEANLINESS, AND FFR DETERMINATION. In October of each year, all pumpkin fruit were harvested and weighed (Table 2 ). All harvested fruit were rated for the presence of intact soil on the surface of the fruit. Pumpkin fruit were rated qualitatively on a scale where one equaled fruit with any soil present on the surface (i.e., dirty) at harvest or zero equaled fruit with no soil present on the surface (i.e., clean) at harvest. In both years, the percentage of harvested clean fruit was calculated for each cover crop mulch treatment. At Wooster in 2002 all pumpkin fruit were rated for symptoms of FFR at harvest. Pumpkin fruit were rated qualitatively on a scale where zero equaled fruit with no symptoms of FFR or one equaled fruit with symptoms of the disease (Fig. 1). The number of fruit infected and percent yield loss (PYL) because of FFR were calculated for the Wooster location in 2002.

\section{Statistical analysis}

Analysis of variance [ANOVA (PROC GLM; $P=0.05$ )] was done with SAS (version 9.1; SAS Institute, Cary, NC) to determine the effects of cover crop treatment on total number and weight of orange, green, and culled fruit; average weight of orange fruit; and total weight and yield of marketable orange fruit. Percent marketable orange fruit, percent groundcover, and biomass production were calculated at pumpkin planting and harvest. The relationship between the percentage of groundcover and biomass production at harvest and the percentage of clean fruit and percent groundcover at harvest was explored for each site in both years. The percentage of Fusarium-infected fruit and PYL due to FFR were calculated for each cover crop mulch treatment at the Wooster location in 2002. Additionally, at Wooster in 2002, the relationship between percentage of groundcover at harvest and Fusariuminfected fruit was explored. Pearson's correlation coefficients were calculated using Excel (version 2007; Microsoft, Redmond, WA) and are presented with equations for the least-squares fitted line in Figs. 2-4.

\section{Results and discussion}

EFFECT OF FALL-SOWN AND SPRINGSOWN COVER CROP MULCHES ON NUMBER AND WEIGHT OF ORANGE, GREEN, AND TOTAL NUMBER OF FRUIT IN 2001 AND 2002. In both years, there were significant location by treatment interactions for the total number and weight of orange, green, and total harvested fruit. Therefore, each location was analyzed separately in both years of the study (Tables 3 and 4 ). In
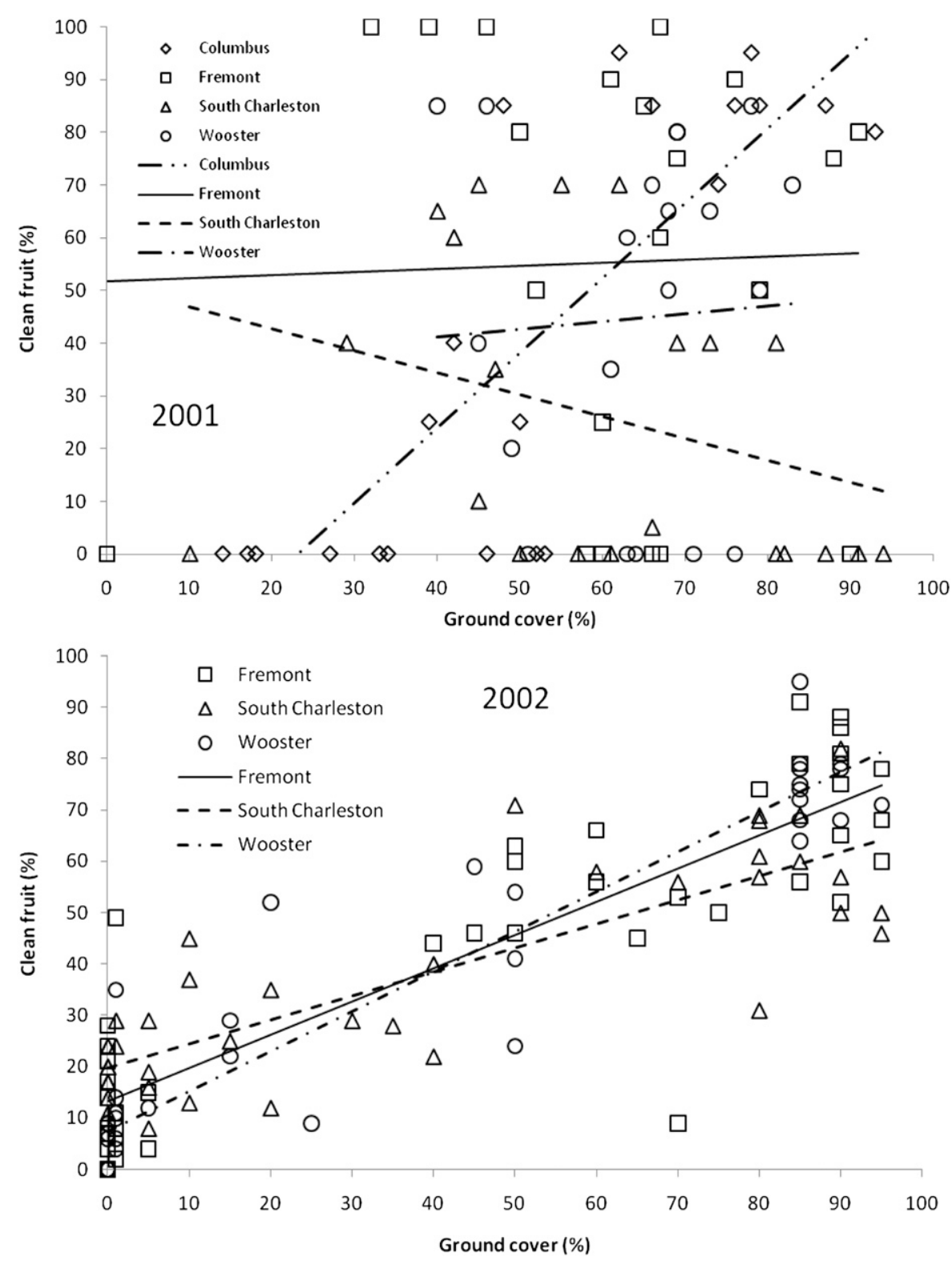

Fig. 3. Relationship between the percentage of clean pumpkin fruit and the percentage of soil surface covered by cover crop mulch at harvest at Ohio Agricultural Research Development Centers research farms in Ohio in 2001 and 2002. Correlation equations in 2001 were $y=1.142 x+32.80(r=0.82)$ for Columbus; $y=0.059 x+51.67(r=0.03)$ for Fremont; and $y=0.415 x+50.99(r=0.32)$ for South Charleston; $y=0.148 x+35.29(r=0.05)$ for Wooster. Correlation equations in 2002 were $y=0.748 x+13.17(r=0.87)$ for Fremont; $y=0.469 x+19.65(r=0.83)$ for South Charleston; and $y=0.776 x+7.45(r=0.95)$ for Wooster, $\mathrm{OH}$. 


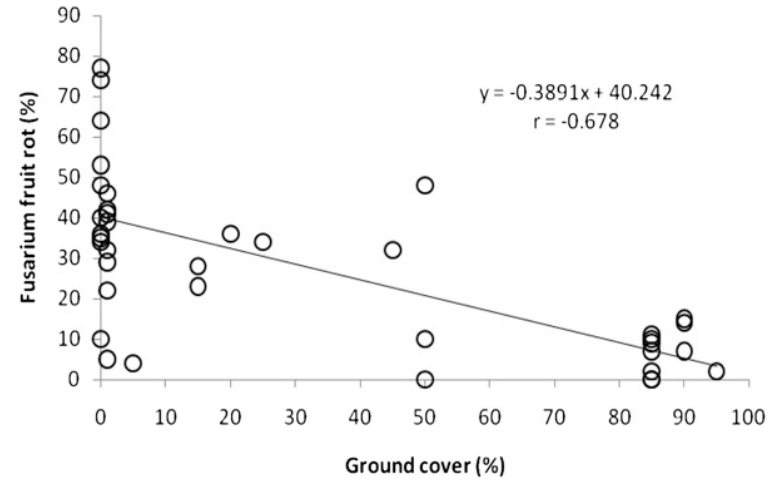

Fig. 4. Relationship between the percentage of pumpkin fruit with fusarium fruit rot caused by Fusarium solanif. sp. cucurbitae race 1 and the percentage of soil surface covered by cover crop mulch at harvest at the Ohio Agricultural Research Development Center in Wooster, $\mathrm{OH}$ in 2002.

general, the number and weight of orange fruit and total fruit weight were higher in bare soil (conventional), fall- or spring-sown, springkilled cover crop mulches compared with spring-sown, living annual medic cover crop mulches (Tables 3 and 4). In both years, pumpkins grown on fallsown winter rye, hairy vetch, winter rye + hairy vetch, or spring-sown oat produced fruit numbers and weights comparable to or slightly higher than bare soil (conventional) production, suggesting that these cover crop mulches had no effects on reducing pumpkin yield. In both years, the number and weight of pumpkins grown in spring-sown, living annual medic cover crop mulches were reduced compared with other cover crop mulches (Tables 3 and 4). This suggests that the living cover crop mulches were competing with the pumpkin planting for available resources, such as water and fertility. In both years, fruit cleanliness was highest in a cover crop mulch consisting of fall-sown winter rye at either seeding rate. Spring-sown oat and fall-sown hairy vetch also improved fruit cleanliness but was less when compared with fall-sown winter rye, winter rye + hairy vetch, or both cover crop mulches. Spring-sown, living annual medic cover crops also improved fruit cleanliness depending on cultivar and year but reduced pumpkin number and weight in both years (Tables 3 and 4).

RELATIONSHIP BETWEEN BIOMASS PRODUCTION AND PERCENT GROUNDCOVER AT PUMPKIN PLANTING AND HARVEST IN 2001 AND 2002. The relationship between cover crop biomass production (i.e., represented as dry weight in tons/acre) and the percentage of groundcover (i.e., percentage of soil surface covered by cover crop mulch) at pumpkin planting and harvest for each site was explored separately for each location in 2001 and 2002. In general, as biomass increased so did the percentage of groundcover on the soil surface at pumpkin harvest (Fig. 2). With the exception of Fremont in 2001, there were no significant differences in groundcover or biomass production at pumpkin planting or harvest between fall-sown rye seeded at 90 or $50 \mathrm{lb} /$ acre (Table 5). In both years, groundcover at pumpkin planting and harvest was highest in fall-sown winter rye and spring-sown 'Sephi' annual medic (Tables 5 and 6). Spring-sown oat and fall-sown hairy vetch provided adequate biomass and groundcover at pumpkin planting but failed to provide enough groundcover to last season-long at some sites each year (Tables 5 and 6). Groundcover and biomass production for spring-sown, living annual medic cover crops varied significantly in both years (Tables 5 and 6). At some sites, groundcover and biomass increased in 'Sephi' from pumpkin planting until harvest. For 'Polygraze' in 2001 and 2002 and for 'Parabinga' in 2002, groundcover and biomass production decreased from pumpkin planting until harvest (Tables 5 and 6 ).

RELATIONSHiP BETWEeN PERCENT CLEAN FRUIT AND PERCENT GROUNDCOVER IN 2001 AND 2002. In both years, the relationship between clean fruit (i.e., without soil debris on surface) and groundcover (i.e., percentage of soil surface covered by cover crop mulch) at pumpkin harvest was explored separately for each location (Fig. 3). At one of four sites in 2001 and at all sites in 2002 there was a strong positive correlation between groundcover and the percentage of fruit that were harvested clean (Fig. 3). In other words, as groundcover increased (i.e., percentage of soil surface covered by cover crop mulch) so did the percentage of clean fruit. This suggests that the presence of the cover crop on the soil surface kept some fruit from coming into direct contact with the soil surface (Fig. 3). At Fremont, South Charleston, and Wooster in 2001, high weed pressure in some cover crop treatment plots affected the percentage of fruit that were clean at harvest. This resulted in higher numbers of clean fruit than expected.

COVER CROP EFFECTS ON THE DEVELOPMENT OF FFR IN WOOSTER, OH, IN 2002. Average PYL based on weight due to FFR was highest at $43 \%$ in bare soil plots. Percent yield loss due to FFR in spring-sown, living annual medic cover crop mulches ranged from $21 \%$ to $37 \%$ depending on species and cultivar. Percent yield loss due to FFR was $27 \%$ in hairy vetch $(50 \mathrm{lb} /$ acre) and $22 \%$ in spring-sown oat. Percent yield losses due to FFR were lowest in fall-sown cover crops consisting of fall-sown winter rye $(50 \mathrm{lb} /$ acre) at 9\%, fall-sown winter rye $(90$ $\mathrm{lb} /$ acre) at $5 \%$, or $4 \%$ in winter rye + hairy vetch $(50 \mathrm{lb} / \mathrm{acre}$ each $)$ cover crop mulch (Table 7).

RELATIONSHIP BETWEEN PERCENT GROUNDCOVER AND SEVERITY OF FFR AT PUMPKIN HARVEST IN WOOSTER, 2002. The relationship between percent groundcover at harvest and FFR development was explored in Wooster in 2002 (Fig. 4). In general, FFR development ranged from $0 \%$ to $80 \%$ in cover crop mulches where percent groundcover was low $(<20 \%$ groundcover) at harvest, from $0 \%$ to $50 \%$ where groundcover was $\approx 50 \%$ at harvest, and from $0 \%$ to $20 \%$ where groundcover was $>75 \%$ at pumpkin harvest. There was a negative correlation $(r=-0.678)$ between percent groundcover and FFR development at harvest (Fig. 4). Thus, in general, the more groundcover present on the soil surface at pumpkin harvest, the fewer number of fruit were infected with FFR, suggesting that the cover crops were beneficial in acting as a physical barrier between pumpkin fruit 
Table 3. Cover crop mulch, seeding rate, and number and weight of orange, green, and total number and weight of 'Magic Lantern' pumpkin fruit harvested at four Ohio Agricultural Research Development Centers (OARDCs) in 2001.

\begin{tabular}{|c|c|c|c|c|c|c|c|c|}
\hline Location $^{\mathrm{z}}$ & Cover crop ${ }^{y}$ & $\begin{array}{c}\text { Seeding } \\
\text { rate } \\
(1 \mathrm{~b} / \text { acre })^{\mathrm{x}}\end{array}$ & $\begin{array}{l}\text { Orange } \\
\text { fruit } \\
\text { per plot } \\
\text { (no.) }{ }^{w}\end{array}$ & $\begin{array}{c}\text { Orange } \\
\text { fruit } \\
\text { per plot } \\
(\mathrm{kg})^{\mathbf{v}}\end{array}$ & $\begin{array}{c}\text { Green } \\
\text { fruit } \\
\text { per plot } \\
(\text { no. })^{w}\end{array}$ & $\begin{array}{c}\text { Green } \\
\text { fruit } \\
\text { per plot } \\
(\mathrm{kg})^{\mathbf{v}}\end{array}$ & $\begin{array}{c}\text { Total } \\
\text { fruit } \\
\text { per plot } \\
{\text { (no. })^{\mathrm{w}}}\end{array}$ & $\begin{array}{c}\text { Total } \\
\text { fruit } \\
\text { per plot } \\
(\mathrm{kg})^{\mathbf{v}}\end{array}$ \\
\hline & BS-no fungicide & 0 & $13.00 \mathrm{c}$ & $61.28 \mathrm{~b}$ & $8.50 \mathrm{ab}$ & $18.27 \mathrm{bc}$ & $21.50 \mathrm{c}$ & $80.50 \mathrm{~b}$ \\
\hline & FS winter rye & 90 & $25.25 \mathrm{a}$ & $127.96 \mathrm{a}$ & $10.00 \mathrm{ab}$ & $25.06 \mathrm{ab}$ & $35.25 \mathrm{ab}$ & $153.03 \mathrm{a}$ \\
\hline & FS winter rye & 50 & $27.25 \mathrm{a}$ & $128.76 \mathrm{a}$ & $10.75 \mathrm{ab}$ & $22.58 \mathrm{abc}$ & $38.00 \mathrm{a}$ & $151.34 \mathrm{a}$ \\
\hline & $\begin{array}{l}\text { SL 'Polygraze' } \\
\text { medic }\end{array}$ & 40 & $16.50 \mathrm{bc}$ & $56.55 \mathrm{~b}$ & $6.00 \mathrm{~b}$ & $8.63 \mathrm{c}$ & $22.50 \mathrm{c}$ & $65.19 \mathrm{~b}$ \\
\hline & SS 'Armor' oat & 110 & $23.00 \mathrm{ab}$ & $102.03 \mathrm{a}$ & $9.75 \mathrm{ab}$ & 21.85 & $32.75 \mathrm{ab}$ & $124.63 \mathrm{a}$ \\
\hline \multirow[t]{3}{*}{ Fremont } & BS-fungicide & 0 & $23.75 \mathrm{a}$ & $144.85 \mathrm{ab}$ & $8.25 \mathrm{~b}$ & $24.18 \mathrm{a}$ & $32.00 \mathrm{ab}$ & $169.03 \mathrm{a}$ \\
\hline & BS-no fungicide & 0 & $14.50 \mathrm{ab}$ & $90.17 \mathrm{bcd}$ & $11.75 \mathrm{ab}$ & $32.28 \mathrm{a}$ & $26.25 \mathrm{ab}$ & $122.45 \mathrm{bc}$ \\
\hline & SS 'Armor' oat & 110 & $22.25 \mathrm{a}$ & $139.00 \mathrm{abc}$ & $6.00 \mathrm{~b}$ & $17.45 \mathrm{a}$ & $28.25 \mathrm{ab}$ & $156.45 \mathrm{ab}$ \\
\hline \multirow{7}{*}{$\begin{array}{l}\text { South } \\
\text { Charleston }\end{array}$} & BS-fungicide & 0 & $24.25 \mathrm{a}$ & $143.22 \mathrm{a}$ & $7.75 \mathrm{a}$ & $30.71 \mathrm{a}$ & $32.00 \mathrm{a}$ & $173.93 \mathrm{ab}$ \\
\hline & BS-no fungicide & 0 & $23.50 \mathrm{a}$ & $137.13 \mathrm{a}$ & $12.50 \mathrm{a}$ & $41.70 \mathrm{a}$ & $36.00 \mathrm{a}$ & $168.33 \mathrm{ab}$ \\
\hline & FS winter rye & 90 & $14.75 \mathrm{a}$ & $93.41 \mathrm{a}$ & $13.25 \mathrm{a}$ & $58.44 \mathrm{a}$ & $28.00 \mathrm{a}$ & $151.65 \mathrm{ab}$ \\
\hline & FS winter rye & 50 & $22.25 \mathrm{a}$ & $128.99 \mathrm{a}$ & $12.00 \mathrm{a}$ & $47.12 \mathrm{a}$ & $34.25 \mathrm{a}$ & $176.71 \mathrm{a}$ \\
\hline & SL 'Sephi' medic & 40 & $22.25 \mathrm{a}$ & $117.21 \mathrm{a}$ & $12.75 \mathrm{a}$ & $32.20 \mathrm{a}$ & $35.00 \mathrm{a}$ & $149.41 \mathrm{ab}$ \\
\hline & $\begin{array}{l}\text { SL 'Polygraze' } \\
\text { medic }\end{array}$ & 40 & $14.25 \mathrm{a}$ & $78.80 \mathrm{a}$ & $10.75 \mathrm{a}$ & $30.01 \mathrm{a}$ & $25.00 \mathrm{a}$ & $108.88 \mathrm{~b}$ \\
\hline & SS 'Armor' oat & 110 & $19.50 \mathrm{a}$ & $116.71 \mathrm{a}$ & $13.00 \mathrm{a}$ & $44.41 \mathrm{a}$ & $32.50 \mathrm{a}$ & $161.12 \mathrm{ab}$ \\
\hline Wooster & SS 'Armor' oat & 110 & $37.25 \mathrm{a}$ & $192.20 \mathrm{a}$ & $14.50 \mathrm{ab}$ & $29.85 \mathrm{a}$ & $51.75 \mathrm{a}$ & $222.05 \mathrm{a}$ \\
\hline
\end{tabular}

${ }^{z}$ Columbus = Waterman Agricultural and Natural Resources Laboratory, Columbus, OH; Fremont = Vegetable Crops Branch $($ OARDC $)$, Fremont, OH; South Charleston = Western Branch (OARDC), South Charleston, OH; Wooster = Snyder Research Farm (OARDC), Wooster, OH.

${ }^{y} \mathrm{BS}=$ bare soil (no cover crop mulch), FS = fall-sown cover crop, SL = spring-sown, living cover crop, SS = spring-sown cover crop mulch. Pumpkins grown in BS-no fungicide treatments did not receive any fungicide maintenance applications for powdery mildew control the entire growing season. All other cover crop treatment plots received regularly scheduled fungicide applications for cucurbit powdery mildew control.

${ }^{x} 1 \mathrm{lb} /$ acre $=1.1209 \mathrm{~kg} \cdot \mathrm{ha}^{-1}$.

"Number of orange, green, and total harvested [orange + green + culled (i.e., not marketable)] fruit per $25 \times 25 \mathrm{ft}^{2}(7.6 \mathrm{~m}) \mathrm{plot}^{\mathrm{w}}\left[625 \mathrm{ft}^{2}\left(58.1 \mathrm{~m}^{2}\right)\right]$.

"Weight of orange, green, and total harvested [orange + green + culled (i.e., not marketable)] fruit per $25 \times 25 \mathrm{ft}^{2} \mathrm{plot} ; 1 \mathrm{~kg}=2.2046 \mathrm{lb}$.

"Means within a column and location followed by the same letter are not significantly different according to Fisher's protected least significant difference test at $P \leq 0.05$.

and the surface of the soil (Fig. 4; Table 7).

\section{Conclusions}

Fall-sown winter rye seeded alone or with hairy vetch produced enough aboveground biomass to provide season-long groundcover for pumpkin production in the midwestern United States. Early establishment (i.e., before hard freezes) in the fall is critical to the success of a winter rye, hairy vetch, or both cover crop mulch in the midwestern United States. Hairy vetch seeded in mid- to late-October in Ohio did not establish because of a hard freeze in central and northern Ohio soon after germination. Spring-sown oat seeded at $110 \mathrm{lb} /$ acre in late-April to earlyMay provided excellent early-to-midseason groundcover in both years and may be an alternative if winter rye, hairy vetch, or both cover crops cannot be established in the fall. In this study, fall-sown hairy vetch seeded at $50 \mathrm{lb} /$ acre and spring-sown oat seeded at $110 \mathrm{lb} /$ acre cover crops failed to provide season-long groundcover, thus reducing their ability to help increase fruit cleanliness at harvest. The faster breakdown of hairy vetch and spring-sown oat compared with fall-sown winter rye during the production season is most likely due to the lower carbon to nitrogen $(\mathrm{C}: \mathrm{N})$ 


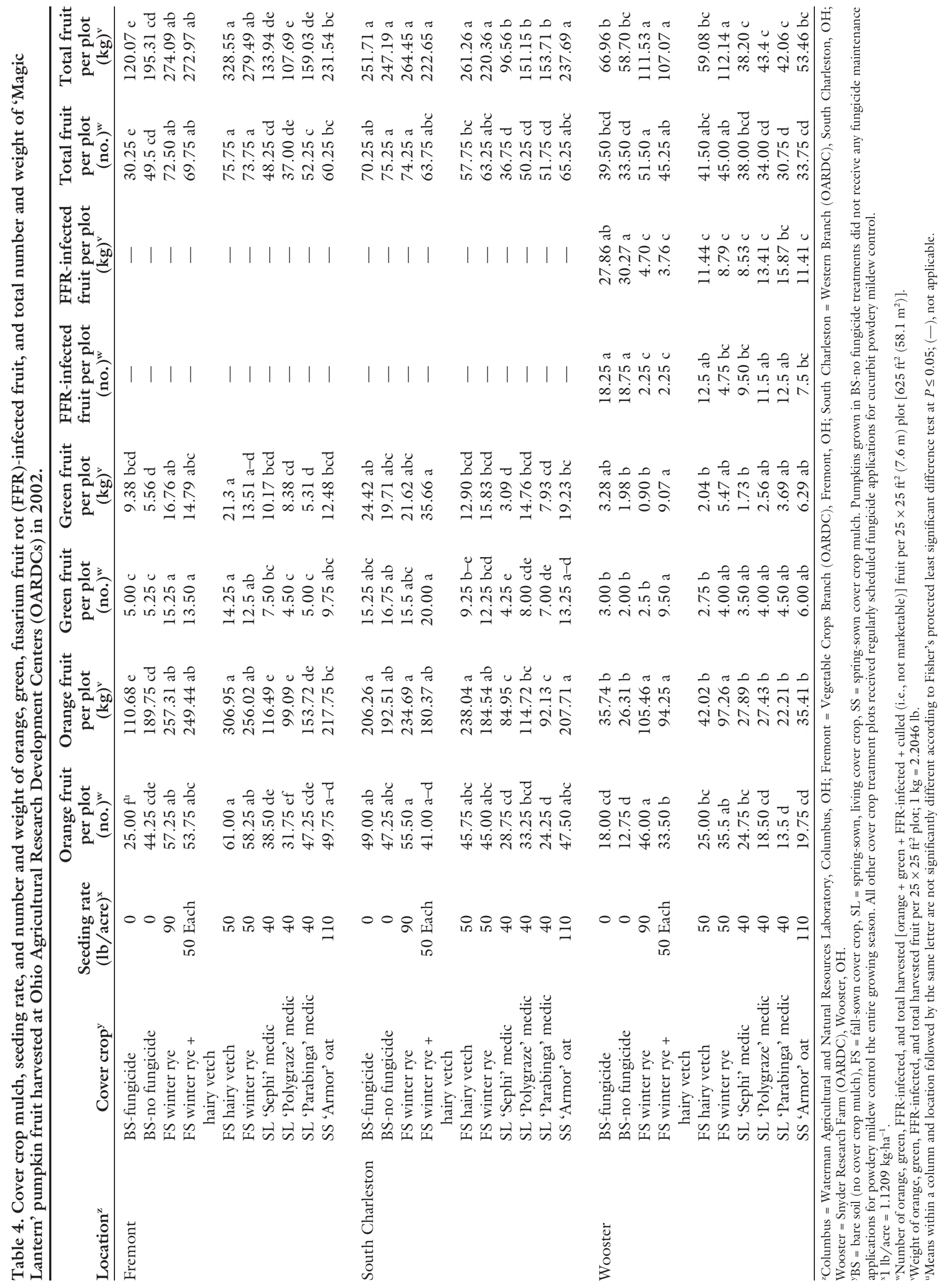


Table 5. Estimated percent groundcover and biomass dry weight at pumpkin planting and harvest and percent clean fruit at harvest for fall- and spring-sown cover crop mulches evaluated at Ohio Agricultural Research Development Centers (OARDCs) in 2001.

\begin{tabular}{|c|c|c|c|c|c|c|c|}
\hline \multirow[b]{2}{*}{ Location $^{\mathrm{z}}$} & \multirow[b]{2}{*}{ Cover crop $^{y}$} & \multirow{2}{*}{$\begin{array}{l}\text { Seeding rate } \\
(\mathrm{lb} / \mathrm{acre})^{\mathrm{x}}\end{array}$} & \multicolumn{2}{|c|}{ Groundcover $(\%)^{\mathrm{w}}$} & \multicolumn{2}{|c|}{ Biomass (tons/acre) ${ }^{v}$} & \multirow{2}{*}{$\begin{array}{c}\text { Clean } \\
\text { fruit }(\%)^{\mathrm{u}}\end{array}$} \\
\hline & & & Planting & Harvest & Planting & Harvest & \\
\hline \multirow{4}{*}{ Columbus } & BS-fungicide & 0 & $0 \mathrm{~d}^{\mathrm{t}}$ & $0 \mathrm{~d}$ & $0.00 \mathrm{~b}$ & $0.00 \mathrm{~d}$ & $28 \mathrm{~d}$ \\
\hline & FS winter rye & 90 & $89 \mathrm{a}$ & $84 \mathrm{~b}$ & $4.49 \mathrm{a}$ & $2.33 \mathrm{~b}$ & $82 \mathrm{a}$ \\
\hline & FS winter rye & 50 & $83 \mathrm{ab}$ & $78 \mathrm{~b}$ & $4.53 \mathrm{a}$ & $2.26 \mathrm{~b}$ & $74 \mathrm{a}$ \\
\hline & SL 'Sephi' medic & 40 & $74 \mathrm{~b}$ & $91 \mathrm{a}$ & $1.04 \mathrm{~b}$ & $2.82 \mathrm{a}$ & $59 \mathrm{~b}$ \\
\hline \multirow[t]{5}{*}{ Fremont } & BS-fungicide & 0 & $0 \mathrm{~b}$ & $0 \mathrm{~d}$ & $0.00 \mathrm{~d}$ & $0.00 \mathrm{~d}$ & $74 \mathrm{ab}$ \\
\hline & BS-no fungicide & 0 & $0 \mathrm{~b}$ & $0 \mathrm{~d}$ & $0.00 \mathrm{~d}$ & $0.00 \mathrm{~d}$ & $50 \mathrm{bc}$ \\
\hline & FS winter rye & 90 & $86 a$ & $86 \mathrm{ab}$ & $2.84 \mathrm{a}$ & $1.84 \mathrm{~b}$ & $63 \mathrm{abc}$ \\
\hline & FS winter rye & 50 & $80 \mathrm{a}$ & $78 \mathrm{~b}$ & $2.14 \mathrm{~b}$ & $1.93 \mathrm{~b}$ & $69 \mathrm{ab}$ \\
\hline & SL 'Sephi' medic & 40 & $80 \mathrm{a}$ & $100 \mathrm{a}$ & $0.87 \mathrm{c}$ & $3.38 \mathrm{a}$ & $35 \mathrm{c}$ \\
\hline \multirow[t]{7}{*}{ South Charleston } & BS-fungicide & 0 & $0 \mathrm{~d}$ & $0 \mathrm{~b}$ & $0.00 \mathrm{c}$ & $0.00 \mathrm{~d}$ & $62 \mathrm{a}$ \\
\hline & BS-no fungicide & 0 & $0 \mathrm{~d}$ & $0 \mathrm{~b}$ & $0.00 \mathrm{c}$ & $0.00 \mathrm{~d}$ & $61 \mathrm{a}$ \\
\hline & FS winter rye & 90 & $71 \mathrm{bc}$ & $65 \mathrm{a}$ & $1.65 \mathrm{ab}$ & $1.91 \mathrm{a}$ & $50 \mathrm{a}$ \\
\hline & FS winter rye & 50 & $55 \mathrm{c}$ & $50 \mathrm{a}$ & $2.46 \mathrm{a}$ & $1.85 \mathrm{a}$ & $65 \mathrm{a}$ \\
\hline & SL 'Sephi' medic & 40 & $83 \mathrm{ab}$ & $15 \mathrm{~b}$ & $1.54 \mathrm{ab}$ & $0.70 \mathrm{bc}$ & $66 \mathrm{a}$ \\
\hline & SL 'Polygraze' medic & 40 & $90 \mathrm{a}$ & $2 \mathrm{~b}$ & $1.14 \mathrm{bc}$ & $0.19 \mathrm{~cd}$ & $57 \mathrm{a}$ \\
\hline & SS 'Armor' oat & 110 & $84 \mathrm{ab}$ & $50 \mathrm{a}$ & $2.21 \mathrm{ab}$ & $1.09 \mathrm{~b}$ & $59 \mathrm{a}$ \\
\hline \multirow[t]{4}{*}{ Wooster } & BS-fungicide & 0 & $0 \mathrm{~d}$ & $0 \mathrm{~d}$ & $0.00 \mathrm{~d}$ & $0.00 \mathrm{~d}$ & $68 \mathrm{a}$ \\
\hline & BS-no fungicide & 0 & $0 \mathrm{~d}$ & $0 \mathrm{~d}$ & $0.00 \mathrm{~d}$ & $0.00 \mathrm{~d}$ & $71 \mathrm{a}$ \\
\hline & FS winter rye & 90 & $80 \mathrm{bc}$ & $72 \mathrm{ab}$ & $2.67 \mathrm{ab}$ & $2.03 \mathrm{ab}$ & $78 \mathrm{a}$ \\
\hline & FS winter rye & 50 & $75 \mathrm{c}$ & $60 \mathrm{~b}$ & $2.59 \mathrm{ab}$ & $1.86 \mathrm{ab}$ & $74 \mathrm{a}$ \\
\hline
\end{tabular}

${ }^{2}$ Columbus = Waterman Agricultural and Natural Resources Laboratory, Columbus, OH; Fremont = Vegetable Crops Branch $($ OARDC $)$, Fremont, OH; South Charleston = Western Branch (OARDC), South Charleston, OH; Wooster = Snyder Research Farm (OARDC), Wooster, OH.

${ }^{y} \mathrm{BS}=$ bare soil (no cover crop mulch), FS = fall-sown cover crop, SL = spring-sown, living cover crop, SS = spring-sown cover crop mulch. Pumpkins grown in BS-no fungicide treatments did not receive any fungicide maintenance applications for powdery mildew control the entire growing season. All other cover crop treatment plots received regularly scheduled fungicide applications for cucurbit powdery mildew control.

${ }^{x} \mathrm{l} \mathrm{lb} /$ acre $=1.1209 \mathrm{~kg} \cdot \mathrm{ha}^{-1}$.

"Average percentage of a $1 / 2 \mathrm{~m}^{2}\left(5.38 \mathrm{ft}^{2}\right)$ area of soil surface covered by cover crop mulch at pumpkin planting and harvest.

"Estimated biomass dry weight collected from $1 / 8 \mathrm{~m}^{2}\left(1.35 \mathrm{ft}^{2}\right)$ area in the center of each cover crop mulch treatment at pumpkin planting (three replications) and harvest (four replications); 1 ton $/$ acre $=2.2417 \mathrm{Mg} \cdot \mathrm{ha}^{-1}$.

"Percentage of clean fruit (i.e., fruit without soil attached) at harvest.

${ }^{t}$ Means within a column and location followed by the same letter are not significantly different according to Fisher's protected least significant difference test at $P \leq 0.05$.

ratios of the hairy vetch and oat. Hairy vetch has a common $\mathrm{C}: \mathrm{N}$ ratio of $\approx 25-30: 1$, and oat has a common ratio of $50: 1$. Both these $\mathrm{C}: \mathrm{N}$ ratios are much lower compared with that of a fall-sown winter rye at 70:1, thus resulting in the quicker breakdown of the mulch on the soil surface.

Annual medics, such as burr medic and barrel medic, which are commonly grown as forage crops in Australia, established well when seeded in lateApril to early-May in central and northern Ohio. Depending on species and cultivar, the annual medic either grew, died back, or died completely during the production season depending on insect pests, foliar disease, and weather conditions. In general, 'Sephi' outperformed 'Polygraze' and 'Parabinga' in biomass production and percent groundcover on different soil types in Ohio. At some sites, 'Sephi' continued to grow during the production season leading to an increase in biomass and percent groundcover by pumpkin harvest where 'Polygraze' and 'Parabinga' died completely or almost completely during the production season. This was most evident in 2002 where 'Sephi' provided excellent season-long groundcover at two of three sites when 'Parabinga' and 'Polygraze' provided early but failed to provide season-long groundcover due to early senescence from summer heat, twospotted spider mite (Tetranychus urticae) damage, and defoliation caused by powdery mildew (Erisiphe polygoni).

This is the first study that supports the relationship between cover crop biomass production and percent groundcover and their effects on increasing fruit cleanliness in pumpkin production. Correlation analysis indicated that there was a positive relationship between biomass production 
Table 6. Estimated percent groundcover and biomass dry weight at pumpkin planting and harvest and percent clean fruit at harvest for fall- and spring-sown cover crop mulches evaluated at Ohio Agricultural Research Development Centers (OARDCs) in 2002.

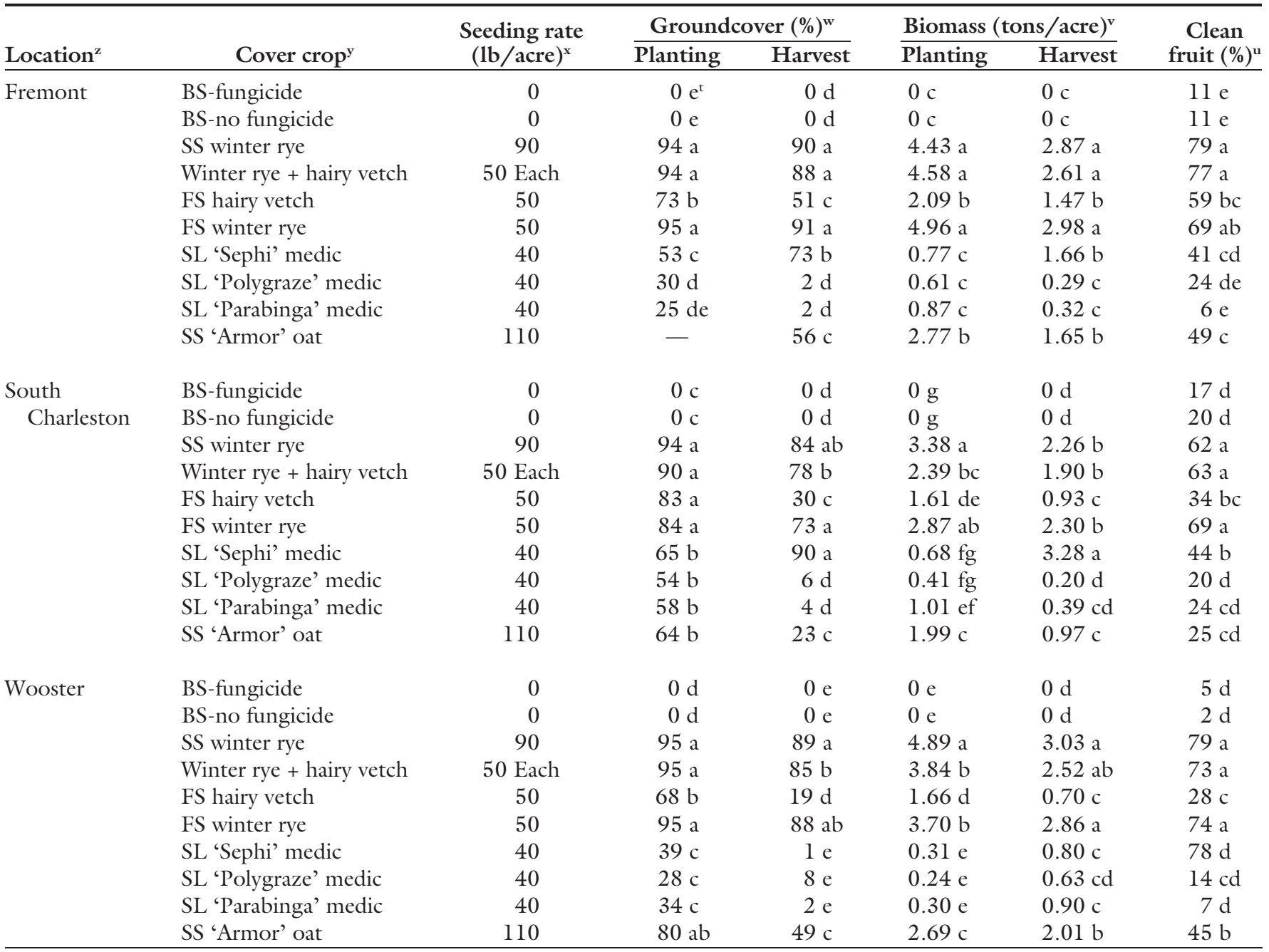

${ }^{2}$ Columbus = Waterman Agricultural and Natural Resources Laboratory, Columbus, OH; Fremont = Vegetable Crops Branch $($ OARDC $)$, Fremont, OH; South Charleston = Western Branch (OARDC), South Charleston, OH; Wooster = Snyder Research Farm (OARDC), Wooster, OH.

${ }^{y} \mathrm{BS}=$ bare soil (no cover crop mulch), FS = fall-sown cover crop, SL = spring-sown, living cover crop, SS = spring-sown cover crop mulch. Pumpkins grown in BS-no fungicide treatments did not receive any fungicide maintenance applications for powdery mildew control the entire growing season. All other cover crop treatment plots received regularly scheduled fungicide applications for cucurbit powdery mildew control.

${ }^{\mathrm{x}} \mathrm{l} \mathrm{lb} / \mathrm{acre}=1.1209 \mathrm{~kg} \cdot \mathrm{ha}^{-1}$

wAverage percentage of a $1 / 2 \mathrm{~m}^{2}\left(5.38 \mathrm{ft}^{2}\right)$ area of soil surface covered by cover crop mulch at pumpkin planting and harvest.

Estimated biomass dry weight collected from $1 / 8 \mathrm{~m}^{2}\left(1.35 \mathrm{ft}^{2}\right)$ area in the center of each cover crop mulch treatment at pumpkin planting (three replications) and harvest (four replications); 1 ton $/$ acre $=2.2417 \mathrm{Mg} \cdot \mathrm{ha}^{-1}$.

upercentage of clean fruit (i.e., fruit without soil attached) at harvest.

${ }^{\mathrm{t}}$ Means within a column and location followed by the same letter are not significantly different according to Fisher's protected least significant difference test at $P \leq 0.05$; $(-)$, not applicable.

(tons/acre) and percent groundcover at pumpkin harvest and a positive relationship between the percentages of cover crop groundcover and clean fruit at harvest. Rutledge (1999), in a review of conservation tillage of vegetables in Tennessee, suggested that crops that can be satisfactorily produced on cover crops can be harvested in cleaner condition, which can reduce cleaning costs to the packer, grower, or processor. The results of this study are similar to another where municipal shade tree leaves were evaluated for their effects on yield and providing clean fruit at harvest in pumpkin production (Wyenandt et al., 2008a).

The effects of fall- and springsown cover crop mulches on FFR development in pumpkin production were evaluated. At Wooster in 2002, cover crops consisting of fall-sown rye at 50 or $90 \mathrm{lb} /$ acre or fall-sown winter rye + hairy vetch sown at $50 \mathrm{lb} /$ acre each significantly reduce incidence of FFR compared with bare soil (conventional) production.
Although the mechanism by which disease was reduced was not studied, it is understood that the pathogen must come into direct contact with pumpkin fruit on the soil surface. In this study, we hypothesized that a cover crop mulch layer may prevent direct contact between the soil-borne pathogen and pumpkin fruit by acting as a physical barrier, thus reducing FFR development. This physical barrier may potentially help to reduce direct infection, the splashing of fungal spores, or have other effects on 
Table 7. Percent groundcover and biomass at planting and harvest, percent clean pumpkin fruit, percentage of fusarium fruit rot (FFR)-infected fruit, and percent yield loss due to FFR at Snyder Farm [Ohio Agricultural Research Development Center (OARDC)], Wooster, OH, 2002.

\begin{tabular}{|c|c|c|c|c|c|c|c|c|}
\hline Cover crop $^{z}$ & $\begin{array}{l}\text { Seeding rate } \\
(\text { lb/acre })^{\mathrm{y}}\end{array}$ & \multicolumn{2}{|c|}{ Groundcover $(\%)^{x}$} & \multicolumn{2}{|c|}{ Biomass (tons/acre) ${ }^{\mathrm{w}}$} & $\begin{array}{c}\text { Clean } \\
\text { fruit } \\
(\%)^{\mathbf{v}}\end{array}$ & $\begin{array}{c}\text { Fruit with } \\
\text { FFR (\%) }\end{array}$ & $\begin{array}{c}\text { Yield loss due } \\
\text { to FFR (\%) } \\
\end{array}$ \\
\hline BS-fungicide & 0 & $0 \mathrm{~d}^{\mathrm{u}}$ & $0 \mathrm{e}$ & $0 \mathrm{~g}$ & $0 \mathrm{~d}$ & $5 \mathrm{~d}$ & $46 \mathrm{ab}$ & $43 \mathrm{ab}$ \\
\hline SS winter rye & 90 & $95 \mathrm{a}$ & $89 a$ & $3.38 \mathrm{a}$ & $2.26 \mathrm{~b}$ & $79 \mathrm{a}$ & $5 \mathrm{e}$ & $5 \mathrm{de}$ \\
\hline Winter rye + hairy vetch & 50 Each & $95 \mathrm{a}$ & $85 \mathrm{~b}$ & $2.39 \mathrm{bc}$ & $1.90 \mathrm{~b}$ & $73 \mathrm{a}$ & $5 \mathrm{e}$ & $4 \mathrm{e}$ \\
\hline SL 'Sephi' medic & 40 & $39 \mathrm{c}$ & $1 \mathrm{e}$ & $0.68 \mathrm{fg}$ & $3.28 \mathrm{a}$ & $8 \mathrm{~d}$ & 25 bcde & 21 bcde \\
\hline SL 'Polygraze' medic & 40 & $28 \mathrm{c}$ & $8 \mathrm{e}$ & $0.41 \mathrm{fg}$ & $0.20 \mathrm{~d}$ & $14 \mathrm{~cd}$ & $32 \mathrm{bcd}$ & $29 \mathrm{bc}$ \\
\hline SL 'Parabinga' medic & 40 & $34 \mathrm{c}$ & $2 \mathrm{e}$ & $1.01 \mathrm{ef}$ & $0.39 \mathrm{~cd}$ & $7 \mathrm{~d}$ & $39 \mathrm{abc}$ & $38 \mathrm{ab}$ \\
\hline SS 'Armor' oat & 110 & $80 \mathrm{ab}$ & $49 \mathrm{c}$ & $1.99 \mathrm{c}$ & $0.97 \mathrm{c}$ & $45 \mathrm{~b}$ & 23 cde & 22 bcde \\
\hline
\end{tabular}

${ }^{2}$ Columbus = Waterman Agricultural and Natural Resources Laboratory, Columbus, OH; Fremont = Vegetable Crops Branch (OARDC), Fremont, OH; South Charleston = Western Branch (OARDC), South Charleston, OH; Wooster = Snyder Research Farm (OARDC), Wooster, OH.

${ }^{y} \mathrm{BS}=$ bare soil (no cover crop mulch), FS = fall-sown cover crop, SL = spring-sown, living cover crop, SS = spring-sown cover crop mulch. Pumpkins grown in BS-no fungicide treatments did not receive any fungicide maintenance applications for powdery mildew control the entire growing season. All other cover crop treatment plots received regularly scheduled fungicide applications for cucurbit powdery mildew control.

${ }^{x}$ Average percentage of a $1 / 2 \mathrm{~m}^{2}\left(5.38 \mathrm{ft}^{2}\right)$ area of soil surface covered by cover crop mulch at pumpkin planting and harvest.

"Estimated biomass dry weight collected from a $1 / 8 \mathrm{~m}^{2}\left(1.35 \mathrm{ft}^{2}\right)$ area in the center of each cover crop mulch treatment at pumpkin planting (three replications) and harvest (four replications); 1 ton/acre $=2.2417 \mathrm{Mg} \cdot \mathrm{ha}^{-1}$.

"Percentage of clean fruit (i.e., fruit without soil attached) at harvest.

"Means within a column followed by the same letter are not significantly different according to Fisher's protected least significant difference test at $P \leq 0.05$.

pathogen growth and dissemination in the soil.

\section{Literature cited}

Abdul-Baki, A.A. and J.R. Teasdale. 1993. A no-tillage tomato production system using hairy vetch and subterranean clover mulches. HortScience 28:106108 .

Abdul-Baki, A.A., J.R. Stommel, A.E. Watada, J.R. Teasdale, and R.D. Morse. 1996a. Hairy vetch favorably impacts yield of processing tomato. HortScience $31: 338-340$

Abdul-Baki, A.A., J.R. Teasdale, R. Korcak, D.J. Chitwood, and R.N. Huettel. 1996b. Fresh-market tomato production in a lowinput alternative system using cover-crop mulch. HortScience 31:65-69.

Blevins, R.L., D. Cook, S.H. Phillips, and R.E. Phillips. 1971. Influence of no-tillage on soil moisture. Agron. J. 63:593596.

Creamer, N.G., B. Plassman, M.A. Bennett, R.K. Wood, B.R. Stinner, and J. Cardina. 1995. A method for mechanically killing cover crops to optimize weed suppression. Am. J. Altern. Agr. 10:157-162.

Creamer, N.G., M.A. Bennett, B.R. Stinner, and J. Cardina. 1996. A comparison of four processing tomato production systems differing in cover crop and chemical inputs. J. Amer. Soc. Hort. Sci. 121:559-568.

Doss, B.D., J.L. Turner, and C.E. Evans. 1981. Influence of tillage, nitrogen and rye cover crop on growth and yield of tomato. J. Amer. Soc. Hort. Sci. 106:9597.

Ellis, M.A., W.F. Wilcox, and L.V. Madden. 1998. Efficacy of metalaxyl, fosetyl-aluminum and straw mulch for the control of strawberry leather rot caused by Phytophthora cactorum. Plant Dis. 82:329-332.

Elmer, W.H., S.F. Covert, and K. O'Donnell. 2007. Investigation of an outbreak of fusarium foot and fruit rot of pumpkin within the United States. Plant Dis. 91:1142-1146.

Everts, K.L. 2002. Reduced fungicide applications and host resistance for managing three diseases in pumpkin grown on a no-till cover crop. Plant Dis. 86:11341141 .

Gallaher, R.N. 1977. Soil moisture conservation and yield of crops no-till planted in rye. Soil Sci. Soc. Amer. J. 41:145-147.

Galloway, B.A. and L.A. Weston. 1996. Influence of cover crop and herbicide treatment on weed control and yield in no-till sweet corn (Zea mays L.) and pumpkin (Cucurbita maxima Duch.). Weed Technol. 10:341-346.

Hoyt, G.D. 1999. Tillage and cover residue affects on vegetable yields. HortTechnology 9:351-358.

Hoyt, G.D. and W.L. Hargrove. 1986. Legume cover crops for improving crop and soil management in the southern United States. HortScience 21:397-402.

Jones, J.N., Jr., J.E. Moody, and J.H. Lillard. 1969. Effects of tillage, no tillage, and mulch on soil water and plant growth. Agron. J. 61:719-721.

Knavel, D.E. and J.W. Herron. 1986. Response of vegetable crops to nitrogen rates in tillage systems with and without vetch and ryegrass. J. Amer. Soc. Hort. Sci. 111:502-507.

Koike, S.T., R.F. Smith, L.E. Jackson, L.J. Wyland, W.E. Chaney, and J.I. Inman. 1997. Cover crops can increase lettuce drop. Calif. Agr. 51(1):15-18.

Louws, F.J., M.K. Hausbeck, J.F. Kelly, and C.T. Stephens. 1996. Impact of reduced fungicide and tillage on foliar blight, fruit rot, and yield of processing tomatoes. Plant Dis. 80:1251-1256.

Masiunas, J.B. 1998. Production of vegetables using cover crop and living mulch-A review. J. Veg. Crop Production $4: 11-31$.

Masiunas, J.B., L.A. Weston, and S.C. Weller. 1995. The impact of rye cover crops on weed populations in tomato cropping systems. Weed Sci. 43:318323.

McKeown, A.W., R.F. Cerkauskas, J.W. Potter, and L. Van Driel. 1998. Longterm evaluation of cover crop and striptillage on tomato yield, foliar disease and nematode populations. Can. J. Plant Sci. 78:341-348.

Mills, D.J., C.B. Coffman, J.R. Teasdale, K.L. Everts, and J.D. Anderson. 2002. Factors associated with foliar disease of staked tomatoes grown under differing bed strategies. Plant Dis. 86:356-361. 


\section{Research Reports}

NeSmith, D.S., G. Hoogenboom, and D.V. McCracken. 1994. Summer squash production using conservation tillage. HortScience 29:28-30.

Paine, L.K. and H. Harrison. 1993. The historical roots of living mulch and related practices. HortTechnology 3:137-143.

Putnam, A.R. 1990. Vegetable weed control with minimal herbicide inputs. HortScience 25:155-158.

Ristaino, J.B. and S.A. Johnston. 1999. Ecologically-based approaches to management of phytophthora blight on bell pepper. Plant Dis. 12:1080-1089.

Rutledge, A.R. 1999. Experiences with conservation tillage in Tennessee. HortTechnology 9:366-372.
Shrestha, A., O.B. Hesterman, J.M. Squire, J.W. Fisk, and C.C. Sheaffer. 1998. Annual medics and berseem clover as emergency forages. Agron. J. 90:197-201.

Sumner, D.R., E.D. Threadgill, D.A. Smittle, S.C. Phatak, and A.W. Johnson. 1986. Conservation tillage and vegetable diseases. Plant Dis. 70:906-911.

Teasdale, J.R. and C.T. Daughtry. 1993. Weed suppression by live and desiccated hairy vetch (Vicia villosa). Weed Sci. 41:207-212.

Wyenandt, C.A., J. Heckman, and N. Maxwell. 2008a. Pumpkin yield and fruit quality responses to leaf mulch and nitrogen. HortTechnology 18:361-364.

Wyenandt, C.A., L.H. Rhodes, M.A. Bennett, and R.M. Riedel. 2008b. Cover crop mulch and fungicide program affect development of septoria leaf spot in processing tomato production. HortScience 43:807-810.

Wyenandt, C.A., R.M. Riedel, L.H. Rhodes, M.A. Bennett, and S.G.P. Nameth. 2010. Survey of Fusarium spp. Associated with Fruit Rot of Pumpkin in Ohio. Plant Health Progress. 18 Mar. 2011. <http://www. plantmanagementnetwork.org/sub/php/ research/2010/pumpkin/pumpkin.pdf>.

Zhu, Y., C.C. Sheaffer, and D.K. Barnes. 1996. Forage yield and quality of six annual Medicago species in North-Central USA. Agron. J. 88:955-960.

Zitter, T.A., D.L. Hopkins, and C.E. Thomas (eds.). 1996. Compendium of cucurbit diseases. APS Press, St. Paul, MN. 